\title{
Article
}

\section{Excremental Art}

\section{Small Wonder in a World Full of Shit8}

\author{
Jojada Verrips \\ University of Amsterdam
}

\begin{abstract}
The representation of defecating and urinating people by artists is a rather old phenomenon, for it pops up in the work of, for instance, Rembrandt. In the $20^{\text {th }}$ century the same can be observed, however with a remarkable difference to past ages. Namely, that the number of artists (painters, performance artists and playwrights to mention only a few) working with shit (as well as with bodily fluids) increased enormously. Especially since the second half of the $20^{\text {th }}$ century and the beginning of the $21^{\text {st }}$, it has become popular to use shit in paintings, performances and plays. This essay deals with the question whether the artworks of so-called shit artists working in the West are just a kind of wild manifestations of decadence and the abject, as so many people claim, or whether they are meant to bring across a particular message with regard to the society and culture in which they are produced. On the basis of the work of the German philosopher Peter Sloterdijk and others, the hypothesis will be launched that one cannot understand this remarkable blossoming of shit in the arts without taking into consideration the fact that we live in an era of neo-capitalism, which implies a horrific transformation of consumption goods bought with money (this eternal companion of shit) into all kinds of waste.
\end{abstract}

Key words: shit art, art, neo-capitalism, consumption and waste

Faeces (as well as farts) are fascinating things. As long as they are still inside a body, no one seems to bother very much about them. However, the moment they leave it, they generally enter the realm of dirt or disgusting matter one has to get rid of as soon as possible, so that they will not pollute us, others or the environment. By using flush toilets, we ban the shit we produce linea recta to the murky underworld of sewage systems, these intestines of our modern world. But not only do we abhor their substance and smell; they very often also keep attracting our attention. In other words, we have an ambivalent attitude towards excrement. Just like the numinous, it forms both a kind of mysterium tremendum which we want to keep at a distance, and a mysterium fascinans of the sorts which keeps us busy. Or perhaps it is better to compare it with the sacred that bears in it both the (idea of the) polluted and the holy. Excrement therefore represents the abject as Kristeva (1982), for instance, has argued in optima forma. Through the ages shit and how to deal or not to deal with it in a literal as well as figurative sense have occupied people's minds and formed a bone of contention in one way or another. Especially when it cropped up in contexts, places and frames where it shouldn't, this could generate hot debates and bitter conflicts (for a revealing history of shit, see Laporte 2000).

\footnotetext{
${ }^{8}$ I want to sincerely thank the peer reviewers for critically reading this essay, Birgit Meyer for her constructive comments and Tereza Kuldova for her patience and efforts to get it published in this journal.
} 


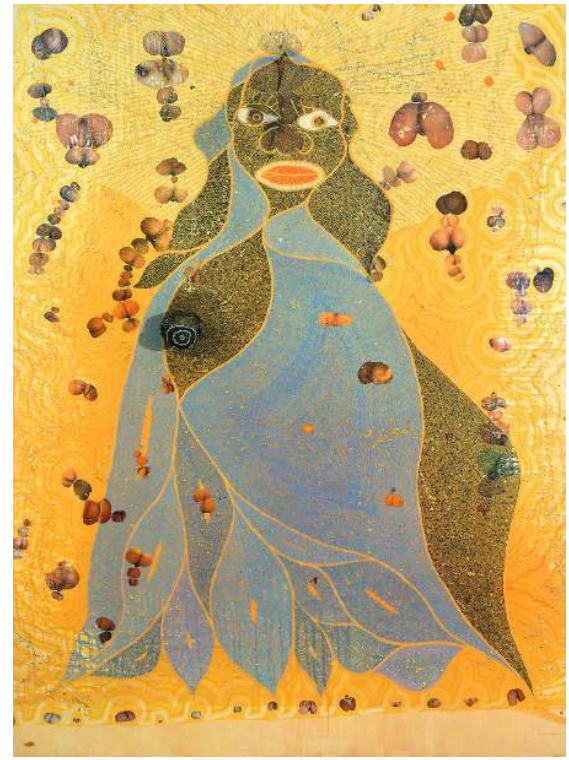

Chris Ofili, The Holy Virgin Mary, 1996.

Recently such conflicts have occurred rather regularly with regard to the work of certain (post)modern artists. A famous case in point is the work of Chris Ofili, a black British artist who uses elephant dung as an ingredient. When his painting The Holy Virgin Mary, in which, along with pornographic clippings, he used the chemically treated faeces of these animals, was shown in the Brooklyn Museum of Modern Art in New York in 1999 as part of the exhibition of British art, Sensation, Mayor Giuliani threatened to withdraw a seven million dollar subsidy if this obscene and blasphemous work was not removed. Although a host of groups and institutions in and outside the US supported him, he was not successful.

It was not the first time that the use of faeces in works of art or the (re)presentation of shit as art provoked campaigns by offended persons and outraged people and I expect that it will not be the last. If one goes back in time, there have been similar kinds of vehement protest against 'arresting images' and performances by artists using not only excrement, but also other bodily matter and fluids, such as blood, pubic hair, smegma, sperm, tears and urine, to name a few (Dubin 1999). But if one delves deeper into this matter, one is struck by the fact that the twentieth century, and especially the second half as well as the early $21^{\text {st }}$ century, seems to show an intriguing increase in both the number of artists who make use of faeces in one way or another, and the number of scandals and campaigns triggered by them. This use of excrement by artists rapidly spread throughout the world, so that by now one can speak of a global phenomenon. However, its best-known representatives still live and work in Europe and the US, as becomes clear when one looks at the background of the artists taking part in the exhibition Scatalogue 30 Years of Crap in Contemporary Art, which was held in Ottawa in 2003 and, as was to be expected, ignited a scandal. ${ }^{9}$ One gets a strong impression that the goals and meanings of their (re)presentations and uses of excrement differ rather radically from the goals and meanings of earlier artists who painted and portrayed shitting (and urinating) people.

The big question, of course, is the direction in which we have to think about this blossoming of what by now is called 'shit art.' The main goal of this paper is to shed more light on this striking development in the world of the arts. The upsurge of scatological elements in artistic work is by no means restricted to specific genres, such as

${ }^{9}$ See http://www.theglobeandmail.com/arts/this-art-is-crap/article1162532 (accessed May 4, 2017) 
painting and performances. They crop up in a broad gamut of genres from literature (which has a longstanding scatological tradition) to plays (with Roi Ubu of Alfred Jarry as one the most notorious and famous examples) and operas, from caricature and comic strips to cartoons and films. ${ }^{10}$ Though it would be interesting to take into consideration all these genres as well, I will concentrate here on the excremental facets of the work of painters, sculptors and performance artists since the second half of the $20^{\text {th }}$ century and try to interpret their occurrence. But a few general issues have to be dealt with first.

\section{...The big question, of course, is the direction in which we have to think about this blossoming of what by now is called 'shit art.'}

anthropological 'subject/object.' But it is an important phenomenon that deserves more attention than it received so far.

Since Mary Douglas published her seminal work Purity and Danger (Douglas 1966), the study of what is considered to From the moment artists used shit, there have been not only curators and collectors buying and exhibiting their works, as well as gallery owners and museum directors offering them opportunities to show their performances, but also a broad range of scholars who studied their work and published books and articles on it. This contributed to a gradual acceptance of this remarkable art form in certain circles. In a sense, the Ottawa exhibition I mentioned before can be seen as a kind of landmark, for it seems to have been the first that showed only work by artists using crap. Before Scatalogue, this kind of work was merely included in exhibitions devoted to recent developments in modern art, such as Post Human (1992), Abject Art: Repulsion and Desire in American Art (1993) and the already mentioned Sensation (1999). Shit art (as well as its companion 'piss art'), though still controversial, appears to be well on its way to become a fully accepted specialization. And this is exactly what the organizers of Scatalogue were after, for in their view excrement was already a common anthropological subject/object in historical museums. A recent example of an exhibition in which shit played an impressive (olfactory) role is Manifesta 11 in 2016 in Zürich. ${ }^{11}$ Though the number of museums, for instance in the Netherlands, organizing exhibitions in which faeces and manure figure prominently has been rising, I would not dare to say that this is a general trend and that excrement figures now as a common be dirt and to cause disgust received a firm impetus, but only recently have a small number of anthropologists and sociologists developed a focused interest in faeces. However, they deal almost exclusively with such issues as how people perceive and treat this kind of bodily waste (see, e.g., the special issues of Medische Antropologie 1999 and PostcoLoniaL Studies 2002). So far there have been no anthropologists or sociologists who have systematically studied the

\footnotetext{
${ }^{10}$ For other interesting French scatological plays at the end of the $19^{\text {th }}$ century, see Menon (1993). A famous Austrian playwright who wrote a series of faecal dramas is Werner Schwab (1958-1994). A funny scatological play is The Turd of Da Vinci by Roland Topor. Finally, I want to mention Romeo Castellucis play On the Concept of the Face, Regarding the Son of God, (dis)qualified by John O'Mahony (Guardian April 20, 2011) as 'a wrenching piece about the metaphysics of excrement.'

11 Interesting in this connection is the fact that recently at several places in Europe shit museums were opened, for example, in 2015 in Cadelbosco near Piacenza (Italy) and in 2016 on the Isle of Wight (GB). On the internet one can visit such a museum too, see www.scheisse-museum. de (accessed May 4, 2017).
} 
recent upsurge of shit art and how this phenomenon might be interpreted. The sociologist Dubin refers to it in his trailblazing work Arresting Images (Dubin 1992) only in passing, and, in a fascinating essay, the anthropologist Hadolt (1999) concentrates on a particular conflict concerning the excremental work of the Austrian artist Cornelius Kolig. ${ }^{12}$ In my view, it does not seem far-fetched to argue that this budding interest in excrement and faeces amongst anthropologists and other social scientists can be related to the interest of artists in the same matter and that, at least partly, it rests on similar grounds.

It goes without saying that art historians have followed the scatological development in the arts from the beginning. However, their publications tend to be rather specific, for they either contain short overviews of the work of particular artists or concentrate on the oeuvre of one. I only traced one special issue of a journal dealing with shit in the arts, and it was published more than two decades ago (Art Journal 1993), which I find rather remarkable. ${ }^{13}$ The number of publications that deal with the scatological development from a more general viewpoint, while placing it in a socio-cultural frame is scant. The tendency seems to be to emphasize the uniqueness of the work of individual artists, which appears to be fully in line with what they themselves want, and/or to philosophize about its meaning in abstract terms. For instance, the reviewer of Julius' book on the transgressions or offences of art, in which the author classifies the work of shit artists as of the taboo-breaking sort, severely criticized him for lumping together 'disparate artists who really bear very little historical or aesthetic relationship to one another' (F.G. 2002, 164). A striking illustration of abstract philosophizing is the conversation published in October on the Informe and the Abject, in which Hal Foster, Rosalind Krauss, Yves-Alain Bois (all connoisseurs of the latest developments in modern art) and others took part (Round Table 1994). In what follows, I will try to venture onto a different path and to explicitly relate shit art to what goes on in the world in which it is produced, exhibited and eventually sold. But first I will present an overview of the most important artists who incorporated (or excorporated) excrement in their artistic work, as well as a more elaborate sketch of the work of some of them.

\section{Artists and Shit: A Brief Empirical Parade}

Before 1850

In their announcement of Scatalogue, the organizers wrote:

...shit has been a persistent metaphor and medium since the

beginnings of Modernism, inspiring the imagination of many

\footnotetext{
12 In 1979, Kolig started building a personal Paradise in Vorderberg (Austria) in which faeces played a crucial role. The artist was very much inspired by Augustinus' adagium: Inter faeces et urinam nascimur (between shit and piss we are born) expanded by him with morimurque (and we will die). At an exhibition of his faecal art in Klosterneuburg (Austria) in 2009 the public was warned that its moral feelings might be hurt by it (see www.profil.at/gesellschaft/chaos-kot-katzen-besuch-kuenstler-cornelius-kolig-368706 Accessed May 4, 2017).

${ }^{13}$ The pieces published in the journal were based on papers presented in a workshop on scatology and art at the Annual Conference of the College Art Association held in 1990 in New York. For the Sixteenth Century Studies Conference that took place in Cleveland ten years later, Jeff Persels organized a workshop on late medieval and early modern scatology (Persels and Ganim 2004).
} 


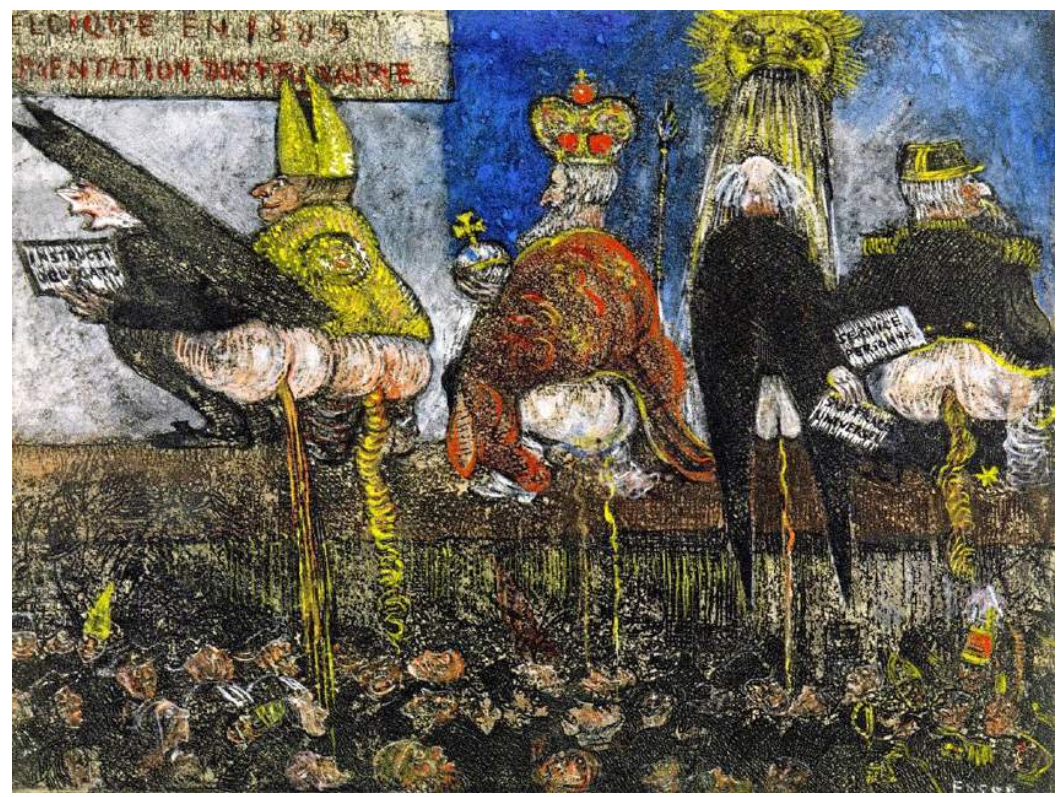

James Ensor, Alimentation doctrinaire, 1889.

influential thinkers and artists. This subject has been an important, tenacious counter-voice to the institutionalization of art, beguiling artists such as Duchamp, the Viennese Actionists, Manzoni and Hammons. ${ }^{14}$

Though they are probably right that shit has been a great source of inspiration since the beginnings of Modernism, it cannot be denied that it was also long before. One only has to think of the work of the classical authors Aristophanes and Juvenal and later Rabelais and Swift (Esty, 1999), who excelled in excremental writing. Several famous pre-modern artists, such as Hans Baldung Grien, Breughel Sr., Paul Veronese and Rembrandt, have painted, drawn or etched defecating and urinating people. A scatological topic that 'appeared with considerable frequency in seventeenth- and eighteenth-century painting and caricature' was clyster syringes, used to administer enemas (Dixon 1993, 28). Here I do not want to delve into such questions as to why artists in the pre-modern era produced this kind of work, what it meant and how it could be related to the societal and cultural context in which it was made and consumed, for that would require another paper, although we could say that some of these works undoubtedly fascinated because of their pornographic character. I only want to make clear that using scatological themes in works of art has a very long history and was not invented in the second half of the nineteenth century when modern art entered the stage.

\footnotetext{
${ }^{14}$ Almost two decades before Ofili caused a scandal by using elephant dung in his controversial painting of the Virgin Mary, David Hammons made sculptures with the same shitty material (Fusco 2001, 41).
} 
Faeces and Art Between 1850 and 1950

In the 1880s, the Belgian artist James Ensor made several works explicitly showing defecation and faeces. Well-known is his Alimentation Doctrinaire (1889), representing a series of authorities, such as a king, a general and a bishop, who sit on a wall and shit on the masses below them, while the sun above is vomiting. According to Canning, this piece was Ensor's 'most political statement and his most direct use of scatological imagery' $(1993,53)$. In the first half of the 20th century, several artists made use of excrement in their work. The Dadaist Kurt Schwitters, for instance, incorporated faeces, urine and other kinds of waste material in his sculpture The Merzbau, which he created in his own house. According to the curator of the exhibit, this sculpture is 'a kind of fecal smearing - a sick and sickening relapse into the social irresponsibility of the infant who plays with thrash and filth.' 15 It is clear that we are confronted here with a (rather vulgar) Freudian characterization, not unusual with regard to pieces of art made in this period in which shit crops up. Two famous Surrealists, Salvador Dalí and Joan Miró, shocked their colleagues and audiences with the paintings The Lugubrious Game (1929) and Man and Woman in Front of a Pile of Excrement (1935) (Julius 2002, 110/11). Dali's canvas shows a man who evidently has shit in his pants and has soiled one of his legs, and Miró's shows exactly what the title says. Dalí's work was passionately discussed by the doyen of Surrealism, Breton, and his opponent, the 'excremental philosopher' Bataille (Bataille 1994, 24-31). Both tried to appropriate the piece of art for their own goals.

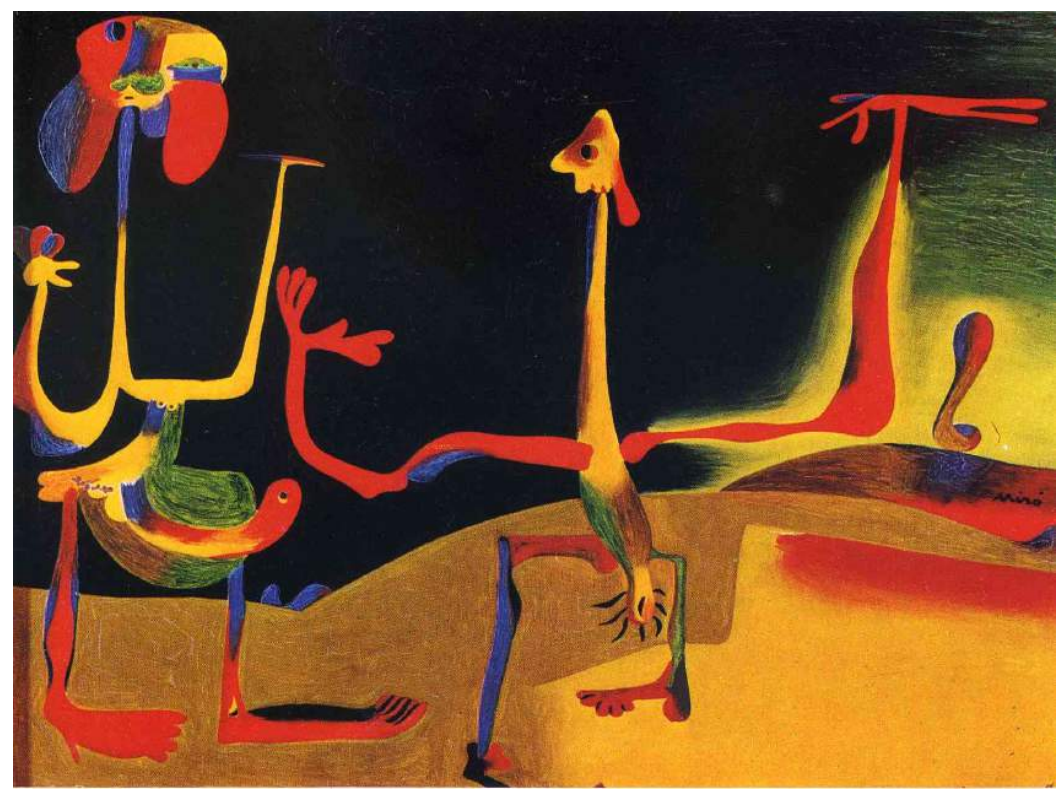

Joan Miró, Man and Woman in Front of a Pile of Excrement, 1935.

15 See www.poopreport.com/intellectual/Content/Scheisse/scheisse.html (accessed May 4, 2017). 
Whereas Breton mentions only in passing the excremental motif in $L e$ feu Lugubre, and hovers on the edge of interpretation in his wish to preserve the enigmatic quality of the painting, Bataille focuses on images of sexual perversions, and makes of 'the ignoble stain' a central element of his detailed psychoanalytical interpretation of the painting, read in terms of the Oedipal scenario of punishment, castration and ignominy, supporting his argument via explicit reference to Freud's theory of dream s (Adamowicz 2003, 6).

Though Dalí tried to keep the middle road in this debate, there are strong indications that he tended towards Bataille's position, for he later scorned what he called 'toilet paper revolutionaries' for their fear of

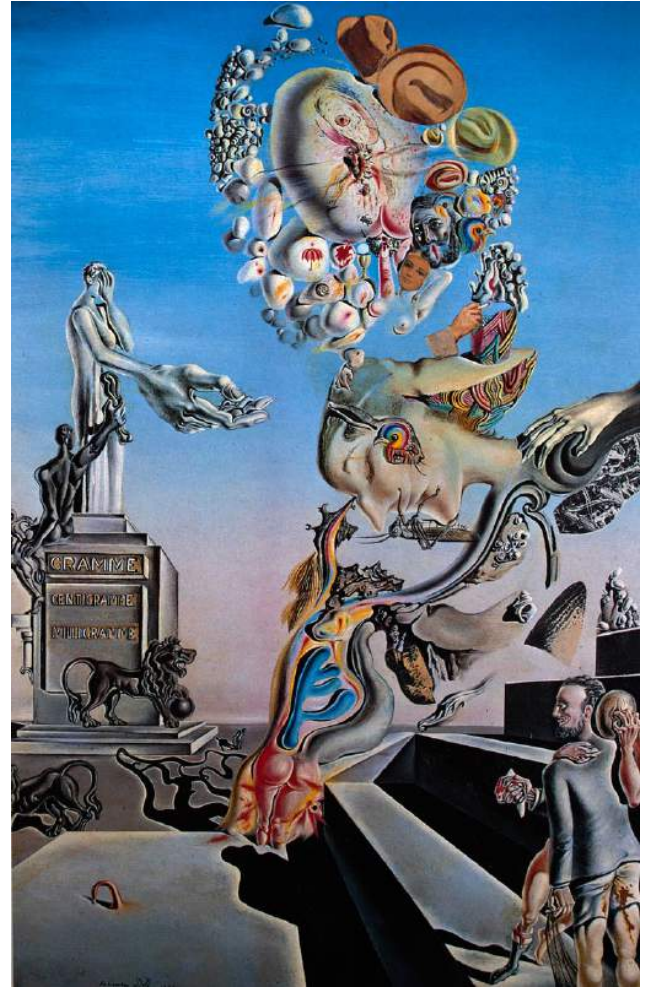

Salvador Dalí, The Lugubrious Game, 1929. shit and the anus, these preeminently human phenomena that therefore needed transcendence (Adamowicz 2003, 9). Dalí's fascination with faeces and the anus became manifest in several other works too, for instance, the painting of his sister with soiled buttocks (Hennig 2000, 180). Along with these artists, there have been a few others (Picasso, for instance) in the first half of the $20^{\text {th }}$ century who also produced scatological pieces, but their number is, as I already remarked, relatively small in comparison with that of the second half. ${ }^{16}$ Moreover, their nature and meaning underwent a transformation. Whereas the products of at least the Surrealist painters mentioned here were rather classical in form and technique and clearly demonstrated (an intended) return of the repressed (on canvas) in the Freudian sense, the excremental paintings, sculptures and performances (as well as the films and videos made of them) that became popular from the sixties onwards deviated from this. From a source of inspiration to depict, represent and perform certain scatological scenes, Freud's ideas about the popping up of the repressed (Fusco 2001, 41) became an intellectual tool to decode and interpret these artistic products. Though I find Freud's view on the return of the repressed fascinating, I nevertheless consider it to

${ }^{16}$ For some humorous remarks from famous modern artists about art and shit, see Silk (1993). 


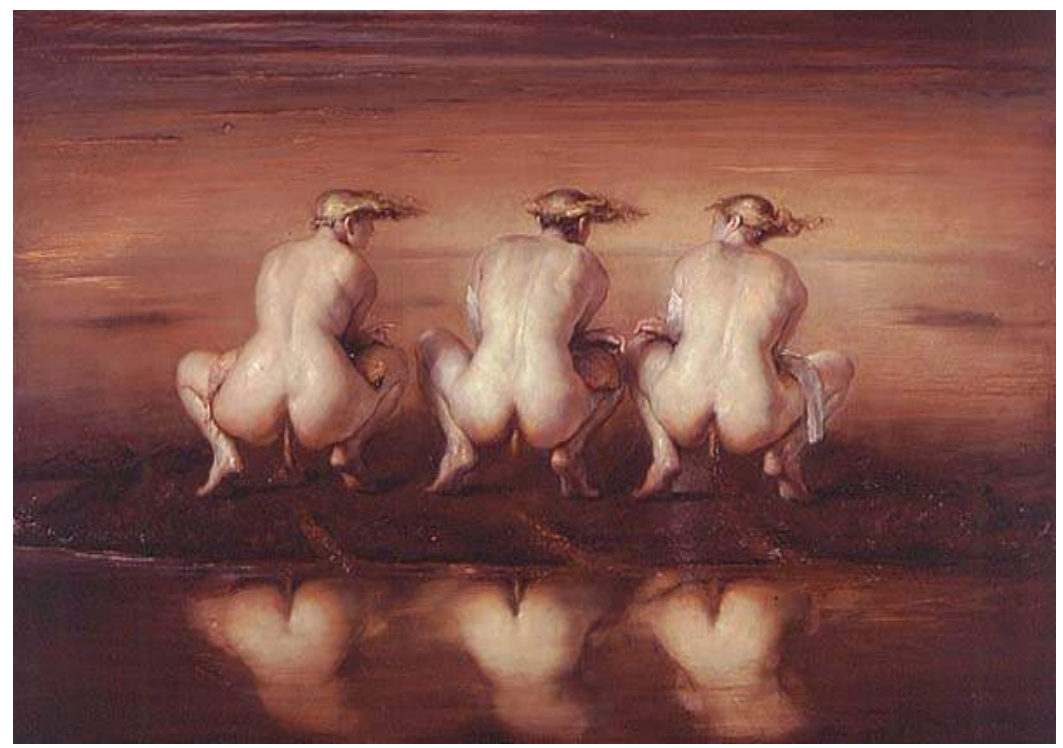

Odd Nerdrum, Shit Rock, 2001.

be of limited value to better understand shit art, because it overlooks the significance of the socio-cultural contexts in which it pops up or, to say it in other words - it perceives it too much as an individual idiosyncrasy.

\section{Shit Art After World War II until Now}

Let me try to sketch the developments on the scatological front after the World War II. This is no easy task, for one is not only confronted with an impressive increase in the number of artists engaging in shit art, but also with a seemingly endless series of apparently unique works and performances that defy any simplifying categorization or classification. However, on closer inspection one soon discovers that there appears to be a kind of order in the chaos or that it is possible to discern a limited number of closely related, though different subgenres in this field. On the one hand, one can observe a continuity in the production of traditional works of art, for people kept on making paintings and sculptures. On the other hand, there has been a radical change, since several artists from the sixties onwards started to use their own and/or other people's bodies in creating artistic events (as well as objects) and even to present these bodies as art works proper (Schneider, 1997, L'Art, 1999, Alfano Miglietti, 2003). The extremely volatile performance art came into existence. Even though volatile, this new art form was almost always preserved through pictures and (video) films. As Weibel has observed: 'The human body was no longer represented in an anthropomorphic sculpture (or even abstracted like in a Moore sculpture), but utilized for sitting, walking, sleeping, eating, pissing, using objects in various ways' (2002, 663), and for shitting, as I would like to add. In a sense, the representation was replaced with reality or by real activities and the 


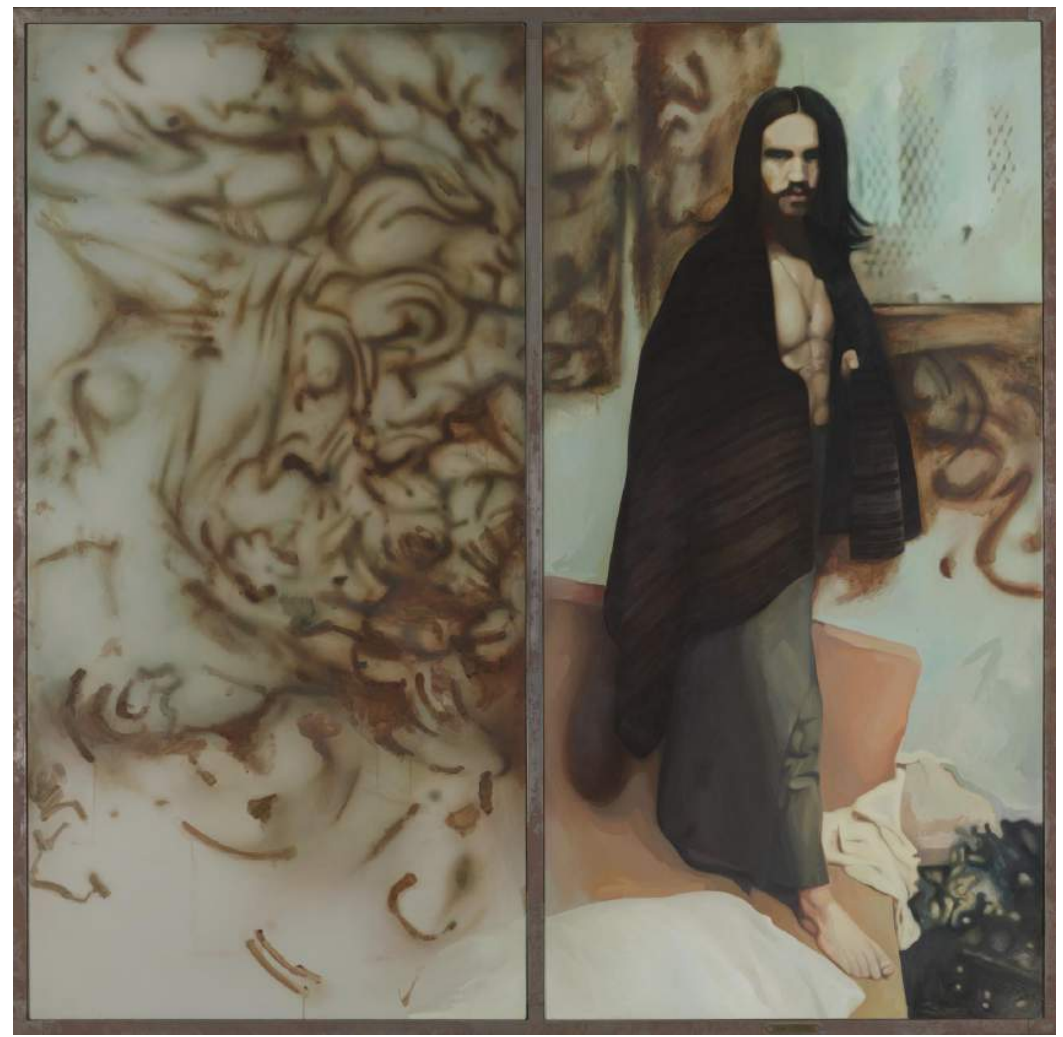

Richard Hamilton, The Citizen, 1981-3.

image was de-framed, though photography often reframed it again (Weibel 2002, 664, $669)$.

Since the list of artists who produced paintings, sculptures (and photographs) representing shit or shitting people since the second half of the 20th century is too long to be given in full here, I will limit myself to just mentioning a few eye-catching examples. Odd Nerdrum made the painting Shit Rock (2001), which shows three squatting naked women (reminding one of the three Graces) who sit with their backs toward the viewer and shit in a kind of canal reflecting their voluptuous buttocks. The art historian Kuspit, who dealt with this work in an article on perversion in art, made the following, rather cryptic comment on it: 'Odd Nerdrum shows them defecating in what looks like homage to the sun. But the long stool looks like a penis, suggesting that Nerdrum also worships the 
phallic woman. ${ }^{17}$ In the early eighties, the British artist Richard Hamilton painted The Citizen, representing one of the Northern Irish prisoners who participated in the socalled Dirty Protest against prison authorities and the British government for not treating them as political prisoners, which lasted from 1978 to 1981. It shows a Christ-like man wrapped only in a blanket, portrayed against the background of a wall smeared with faeces. ${ }^{18}$ Later on I will come back to this painting, for in my view there is an interesting family resemblance between the self-created faecal squalor it shows and particular scatological performances as they were staged by, for instance, the Wiener Aktionisten Günter Brus and Otto Mühl in Austria in the early sixties of the last century. ${ }^{19}$ In these performances, shit and blood played a dominant role. In the seventies, Mühl, certainly one of the most outspoken shit artists in the world, started a socio-sexual utopian commune, first in Vienna and then in the countryside in Friedriechshof, in which collective property and free sex was the rule. In 1991, he was convicted to seven years in prison because he was found guilty of criminal offences against public morals and drug laws. During his imprisonment, Mühl made a whole series of paintings in which, along with sperm and blood, shit and shitting emphatically occurred; they included White Chocolate (1994), Homage to Beuys (1994), Sexual Molestation $(1995)^{20}$, Eternal Spirit (1996) and Shit Picker (1997) (Noever 1998). After he was released, these and other paintings were exhibited in Vienna and, as was to be expected, caused a scandal of a familiar type. In an interview with Peter Noever, he gave the following answer when asked how he would describe his painting:

As actionist concept painting. My background is actionism. I describe myself as polymorphously perverse. As an actor of polymorphous perversities. I do this quite deliberately and employ it as an assault. My vocabulary is shit, urine, sperm, sexuality, sodomy. I use all of this deliberately and employ it as an assault, as a way to attack moral taboos. I am interested in doing away with everything that constricts sexuality (Noever 1998,19).

In the early 1980s, the famous British couple Gilbert \& George produced such pieces as Shit (1982) and Shit Faith (1982), images of turds coming out of four buttocks facing each other and of a man receiving shit in his mouth. In the 1990s, their exhibition The Naked Shit Pictures showing their latest framed photo pictures, some of which were full of faeces, arranged in specific compositions and with such titles as Naked Shit, Shitty World and Spit

17 See www.artnet.com/Magazine/features/kuspit/kuspit6-10-02.asp (accessed May 4, 2017). Already in 1981 Nerdrum painted a similar kind of work showing just one defecating woman. In the same year the controversial German artist Blalla W. Hallmann painted six people shitting on each other (Funken 1998, 350-51).

${ }^{18}$ Stuart Brisley created a similar painting (Mairead Farrell, Dirty Protest) in 1995. This sort of painting reminds one of David Nebrada, who made self-portraits with the face covered with shit (Ardenne 2001, 242). For short biographies of these Austrian artists, see L'Art (1999, 448/49, 461).

19 This painting shows a remarkable family resemblance to the print Kärnten bläht auf (2001) by the Austrian artist Cornelius Kolig, who, like Mühl, produced many faecal artworks.

${ }^{20}$ For a short biography of these British artists, see L'Art (1999, 452). 
on Shit, toured through Europe. In an interview with the Dutch journalist Jhim Lamoree, Gilbert once said: 'We show something to the public that it has learned to perceive as totally unacceptable. We make a history of two thousand years of civilization and morals look like shit, because it tried to inculcate into us that nakedness and faeces are bad' (Parool November 3, 1997 Translation JV). In another interview they remarked: 'We are naked, full of shit - and that is what we want to show.'

In the beginning of the new century the number of artists making paintings, sculptures and photographs of or with shit significantly increased. Two hilarious cases are the Shit Fountain (2004) by the American Jerzy S. Kenar and the Complex Pile (2007) by shit artist par excellence Paul McCarthy. Kenar put his faecal sculpture in front of his gallery in Chicago as a kind of protest against dog shit in the streets of this city, whereas McCarthy constructed a huge inflatable

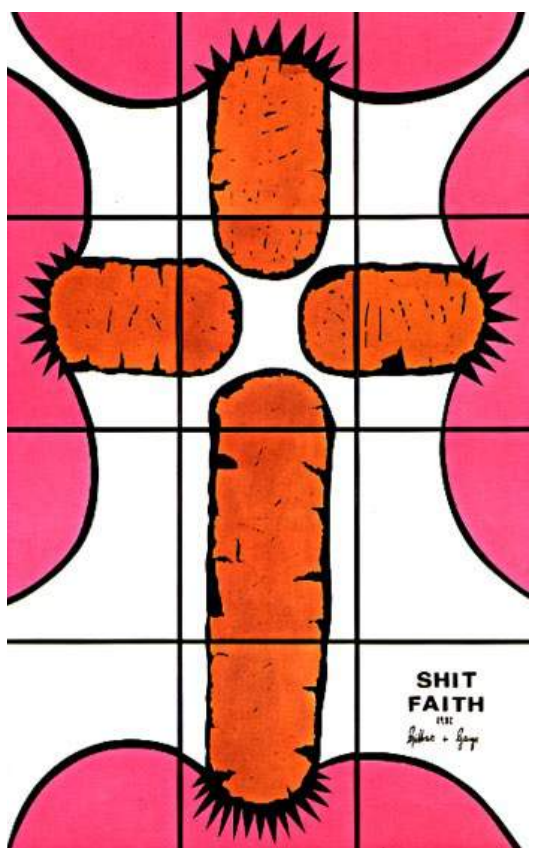

Gilbert \& George, Shit Faith, 1982. dog turd evidently with a similar idea in the back of his mind: a protest against the pollution of the environment. ${ }^{21}$ In 2008, the photographer Andres Serrano, the man who in the late 1980s shocked the world with his picture Piss Christ, once again produced a provocative work, this time a series of photographs of all kinds of animal shit, including a self-portrait of his own poop that disgusted many people. ${ }^{22}$ More impressive and serious, however, I deem the artistic creations or sculptures made by Anish Kapoor and Mike Bouchet. The sculptural installation Between Shit and Architecture (2011) of Kapoor consists of twelve monumental concrete mounds formed by densely textured layers of poured concrete looking like shit that triggers a lot of questions with regard to contemporary architecture. According to the Croatian artist Stefan Haus Kapoor's work stimulates the beholders to think about such crucial issues as '... whose shit are we living in? Who is the "producer"? The state?

21 See http://calumet412.com/post/131750063731/shit-fountain-2004-jerzy-s-kenar-chicago-based and http://www.observatoire-art-contemporain.com/revue_decryptage/tendance_a_suivre.php?id=20120822. (accessed May 4, 2017).

22 Including the art historian Donald Kuspit, for he wrote a devastating critique of the faecal art of McCarthy and Serrano. In his eyes 'their shit symbolizes the comic tragedy that art has become and the tragic comedy that America has become.' See www.artnet.com/magazineus/features/kuspit9-11-08.asp?print=1 (accessed May 4, 2017). 
Is it...Capital?'23 Bouchet 's sculptural creation The Zürich Load (2016) shows a certain family resemblance with Kapoor's creation, for it also consists of a collection of blocs, only a bigger one. As a matter of fact, he transformed 80 tons of shit produced by the inhabitants of Zürich on one day by mixing this mass with concrete, chalk and pigments into almost 300 dried, but nevertheless smelly blocs and showed them, orderly arranged in a rectangle at the exhibition Manifesta 11 in 2016 in this city. Just Like Kapoor's work Bouchet's triggers serious questions with regard to our production of waste and what to do or not to do with it. ${ }^{24}$

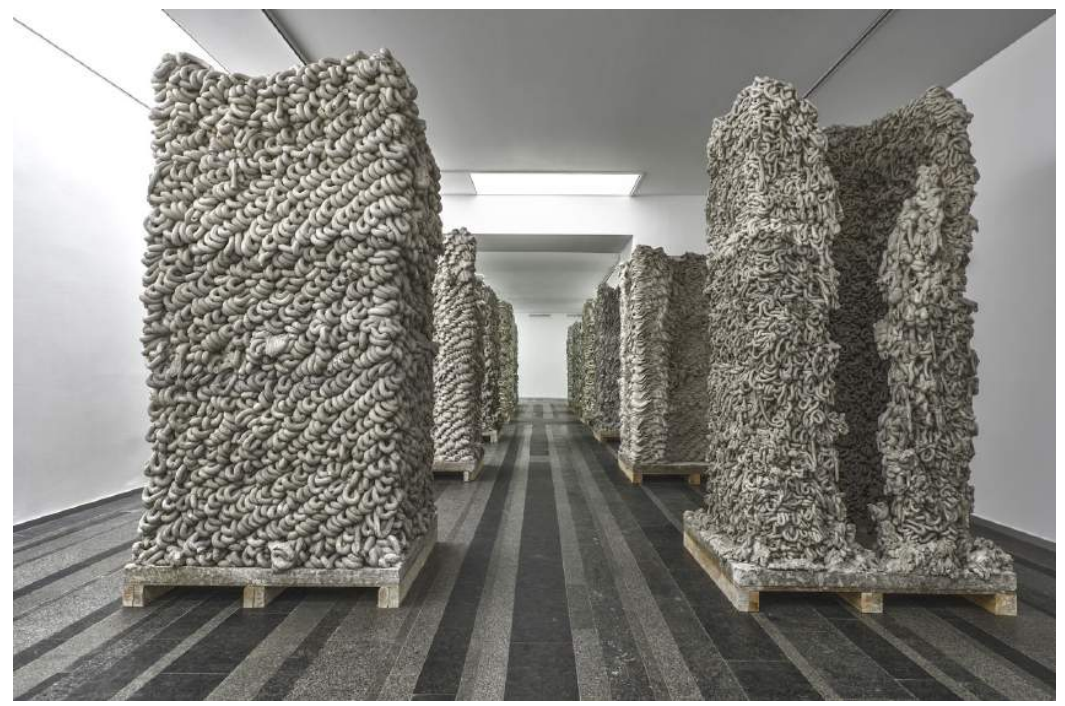

Anish Kapoor, Between Shit and Architecture, 2011.

Along with people who produced imagery of shit and shitting and who put this imagery within classical frameworks, there were and still are also artists who started to use excrement as if it were a kind of paint. The most famous example is the already mentioned Chris Ofili, who began to work with elephant dung in his otherwise pretty paintings. In an interview he once said about this curious combination:

The paintings themselves are very delicate abstractions, and I want to bring their beauty and decorativeness together with the ugliness of the shit and make them exist in a twilight zone - you know they're there together, but you can't ever really feel comfortable with it.

23 See http://stefanhauswords.blogspot.nl/2012/06/between-shit-and-architecture.html (accessed May 4, 2017).

${ }^{24}$ See www.srf.ch/kultur/kunst/faekalkunst-an-der-manifesta-sorgt-fuer-dicke-luft (accessed May 4, 2017). 
A remarkable subgenre of shit art is produced by artists who use their body - as one of them, Jacques Lizene, once aptly remarked - as a 'tube de peinture' (Ardenne 2001, 242). In a satirical message on the Internet, Wolfgang Lettl wrote on this new development: "Eat and Shit Art" (...) implies that the artists eat the paint; the work of art is then the piece of paper with which they clean their buttocks. Retouches with a finger afterwards seldom take place'. ${ }^{25}$ A good example is Keith Boadwee whose '...videos, which are installed in the gallery along with the finished products of his painterly efforts, show the artist, completely "unveiled," crouching indecorously over canvases spread along the floor and ejecting streams of paint out of his anus' (Jones 1998, 100). ${ }^{26}$ There is a salient family resemblance here with the famous sculpture Tale (1992) by Kiki Smith representing 'a naked woman on all fours, faeces trailing from her anus, as if she were in the midst of some evolutionary metamorphosis from animal to human. Helpless, vulnerable, exposed - the sculpture epitomizes abjection' (Kauffman 1998, 42). ${ }^{27}$

Some decades before artists used their own body as a tube that they emptied on canvas to exhibit (and even sell) their art products later, the Wiener Aktionisten had already staged performances in which they defecated (and urinated) in public (places such as university buildings). However, their actions were only conserved (or framed if one wishes) in pictures, films or videos. Famous and notorious, for instance, is Günter Brus' performance Der helle Wahnsinn (the absolute craziness) in Aachen (1968) (for pictures of Brus shitting, peeing and doing other shocking things with or to his body, see Weibel 1970). Along with Brus, the aforementioned Otto Mühl played a dominant role in this taboo breaking and strongly antifascist avant-garde movement that caused a lot of fuss in Austrian society and abroad because of its obscene, often outspoken scatological activities. Mühl organized, for example, so-called Materialaktionen, a kind of happenings '...with naked actors engaging in real rude acts of sexual violence and rape' (Vogel 1997, 250). These happenings formed the basis for a few deeply provocative films such as Sodoma (1970), in which a gamut of sadomasochistic activities is shown and which is dedicated to shit-eaters; another provocative film by Mühl is Mama und Papa (1963-1969, see Vogel 1997, 250-55). Sodoma contains the so-called Scheisskerl-Episode (shit-man episode) in which coprophilia in all its variations is staged. Vogel warns not to quickly disqualify Mühl's work as pure pornography, arguing that it intends to lay bare the dark side of the society in which he was born, a society that was involved in two world wars and participated in Nazi terror.

\footnotetext{
25 Original German text: "Eat and Shit Art"...besteht darin, dass die Künstler die Farbe essen; das Kunstprodukt ist dann das Blatt, mit dem sie sich den Hintern abwischen. Nachträgliche Retuschen mit dem Finger werden nur ganz sparsam angebracht.' See http://www.lettl.de/texte/eat.html (accessed May 4, 2017).

26 There is a striking parallel here with so-called piss artists, who urinate on canvasses or other materials. For instance, the pop artist Andy Warhol and the photographer Andres Serrano used urine in their work. There are many artists who have done this as well. See the text piss art: images of urination in $20^{\text {th }}$ century art by Christopher Chapman (1998) on the Internet at http://ensemble.va.com.au/array/chap 00.html (accessed May 4, 2017).

27 In 1992, Smith had already made a wax sculpture Pee Body, representing a crouching female figure with long strings of glittering beads coming from between her legs. See also the still of the video production Heidi (1992) by Mike Kelley and Paul McCarthy, which shows Heidi and her grandfather looking at someone shitting a sausage into a dirty pan (Monk et al. 2000, 62-63).
} 
Later other artists used shit or material that looked like shit (such as chocolate) to smear on their own or others' bodies or on material objects. Well-known are, for instance, the black-and-white pictures made by performance artist Mike Kelley of his colleague Bob Flanagan and his partner Sheree Rose, while she was 'eerily humping a stuffed toy rabbit (appropriately, since she is dominant, she is on top), while Bob, a "bottom," is smeared with excrement, wiping his bottom' (Kauffman 1998, 22/23, L'Art, 1999, 26/27). This was a study for the diptych Manipulating Mass-Produced Idealized Objects/ Nostalgic Depiction of Innocence of Childhood (1990), which is just like other works by Kelley of an outspoken infantile, anal and scatological nature. However, if one takes into consideration the title, the soiling of stuffed animals with excrement seems to point to more than just a wish to stage/show an infantile interest in shit. In other words, a more multi-layered meaning of this intriguing study might be involved, a point to which I will return later.

\section{...shit is used to convey particular messages about the thin and superficial nature of our civilization or that of others and how lurking beneath the veneer is a deep, excremental darkness fond of making it to the surface.}

Another performance artist who is interesting in this context is Karen Finley. 'In the late 1980s, performance artist and NEA grant recipient Karen Finley took off her clothes and smeared herself with chocolate to symbolize the shit women put up with.' The idea for this performance, entitled We Keep Our Victims Ready, Finley got from a 16-year-old girl who, according to the newspapers, was found alive in a Hefty bag covered with faeces. In an interview the feminist performer remarked: 'I use chocolate because it's a visual symbol that involves eating as well as basically being treated like shit (...) I could use real shit, but we know that happens already - just read the news...'28

The smearing of shit on bodies and things, as it crops up in the works, actions and happenings of such artists as Brus, Mühl, Kelley and Finley, strongly reminds one of the Dirty Protest as it was held in 1978 in the Armagh and Long Kesh prisons in Northern Ireland, on the one hand, and the dehumanizing practices of American soldiers in the Abu Ghraib prison in Iraq (2003/04), on the other. Whereas the prisoners in the first case decided, for instance, to shit in the corners of their cells and smear their faeces on the walls, as is so vividly shown in Hamilton's painting The Citizen, the Iraqi prisoners' guards ordered them to take their excreta out of the toilet pots and smear them on their bodies. The family resemblance is striking and I think not without reason, for it seems that in all these cases shit is used to convey particular messages about the thin and

\footnotetext{
28 See http://old.cinema.ucla.edu/women/carter/carter4.html (accessed May 4, 2017). Finley's work is highly visceral and scatological at times. In her performance The Constant State of Desire (1987), in which she used stuffed animals to smear egg muck on her naked body, she tells her audience 'tales of sticking Cuisinarts and racquetballs and cordless phones up the asses of entrepreneurs... who then "lick the piss and shit off me on Avenue B" - "cause they like it"' (Schneider 1997, 102). Schneider says this is how she shows how the consumption of commodities and identity or selfhood are related, how 'objects as insignias of enviability do not float in a dreamscape of insatiable desire but are dragged screaming into visceral and finite social bodies" (Schneider 1997, 102/03, see also Dubin 1994, 149ff.). This is clearly a fascinating critique of consumer capitalism (of a type also occurring in certain works by Mike Kelley and Paul McCarthy)
} 
superficial nature of our civilization or that of others and how lurking beneath the veneer is a deep, excremental darkness fond of making it to the surface.

Very interesting are the artists who processed faeces in one way or another to transform them into works of art, some of which found their way to prestigious exhibitions and important collections. A famous case is Piero Manzoni's Merda d'Artista. ${ }^{29}$ Gerald Silk's brilliant article on this fantastic piece of art begins with the following apt description:

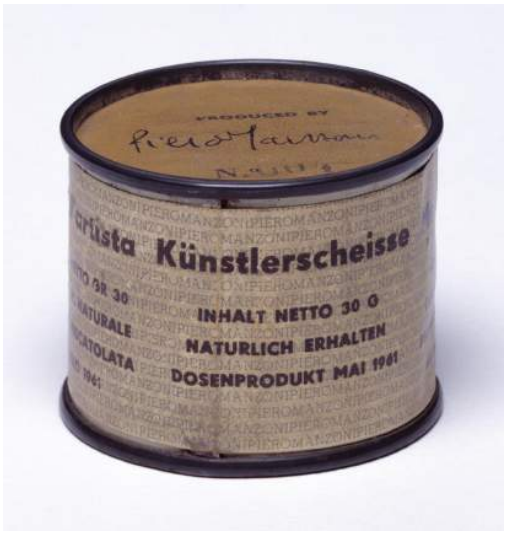

In May 1961, the Italian artist Piero Manzoni packed and sealed ninety cylindrical cans, each containing thirty grams of his own excrement. Atop each tin are the words PRODUCED BY, followed by the signature Piero Manzoni, and a stencilled number designating its place in the run. A label affixed to the body of each consists of rows of the artist's first and last names strung together and repeated over and over. This

Piero Manzoni, Artist's Shit, 1961.

PIEROMANZONIPIEROMANZONI functions as a background on which is printed the words:

Artist's Shit

contents 30 grams net

freshly preserved

produced and tinned

in may 1961

On every can, these words appear in four languages - English, Italian, French, and German. Merda d'artista, to be sold by weight based on the current price of gold, was first exhibited in August of that year at the Galeria Pescetto in Albisola, Italy (Silk 1993, $65) \cdot{ }^{30}$

A few years ago the Tate Gallery paid $£ 22,300$ for can 004 with Manzoni’s faeces. Ironically, The Daily Telegraph of 21 October 2003 wrote: 'The price paid by the Tate for

\footnotetext{
${ }^{29}$ For a short biography of this Italian artist, see L'Art (1999, 459).

${ }^{30}$ An artist who also turned his own excrements into works of art, in this case so-called Tourtes, is Gérard Gasiorowski (Ardenne 2001, 241). The controversial American performance artist Ann Liv Young sells her (sealed) faeces via the Internet and Andres Serrano made photographs of his excrement.
} 
its merda - $£ 745$ per gram - exceeds...the $£ 550$ that the contents of the tin would cost if they were made of 24-carat gold.' The newspaper also mentioned that already 45 of the original 95 (more accurately: 90) cans had exploded and that this exactly was what Manzoni intended. ${ }^{31}$ Silk, however, emphasizes that they were designed to remain closed and therefore are ultimately conceptual (Silk 1993, 68). More relevant in this context is his argument that Manzoni's tins remind one, on the one hand, of the association of gold and shit in mythology and alchemy first and Freudian psychoanalysis later and, on the other, of products of industrial manufacture or commodities. According to Silk, in creating Merda d'Artista, Manzoni must have had in mind the production of a piece of art that looked like a real commodity produced on a conveyor belt and clearly referred to the cycle of ingestion, digestion and excretion or - somewhat more abstractly - to consumption-waste cycles. Part of his inspiration for this came from the artists Yves Klein and Arman, who, just like Manzoni, though slightly earlier than he, were also involved in what Silk calls 'the commodification of art.' Arman organized in 1960 the exhibition Le Plein in a gallery in Paris, which he filled up with garbage or "what the artist called "accumulations," which involved "the pseudo-biological cycle of production, consumption, and destruction" that anguished him because "one of its most conspicuous material results is the flooding of our world with junk and recycled odd objects' (Silk 1993, 69).

Though Silk mentions all these interesting aspects of the art made by such avant-garde artists as Arman and Manzoni, he does not connect them in a detailed manner with the kind of world they lived in or - more specifically - with the neo-capitalist mode of production, distribution and consumption in which fertilizer and faeces, commodities and capital, goods and garbage are closely united. In the end, Manzoni more or less figures as an artist who enriched the world with a series of unique artistic products, and not so much with a very particular, though revealing kind of comment or critique on our neo-capitalist society and culture through these products. I would say that precisely the latter is more important than the former. But I am an anthropologist and no art historian.

An artist who clearly works in the same vein as Arman and Manzoni is the British performer Stuart Brisley. He is very interested in excrement, in particular, and all kinds of waste and garbage, which he sees as metaphorical shit, in general. At the end of the $20^{\text {th }}$ century, so he suggests in one of his publications (Brisley 2003), his double R.Y. Sirb or the Curator of Ordure got the suggestion from the Collector of Ordure (another double of Brisley) to establish a Museum of Shit. To found it, he even paid a visit to the Hygiene Museum in Dresden in 2000. In his report on this visit, Sirb alias Brisley wrote that he first introduced the subject The Collection of Ordure by dealing with the following topics: 'The question of shit, its collection, and preservation. Art, shit, and money. The methodologies of collecting and preserving shit. The subject of the redemption of the

\footnotetext{
31 The rumour goes round that one of the cans 'decided to self-destruct' in the Randers Museum of Art in Denmark. In 1989, the artist Bernard Bazile made Boite de merde ouverte de Manzoni (L'Art 1999, 414). The creation of variations of famous works of art is not unusual. Since Duchamp created a ready-made urinal signed 'R. Mutt' as a piece of art in 1917 there have been several artists who came up with similar types of urinals, for instance Sherry Levine with his bronze Fountain (1991).
} 


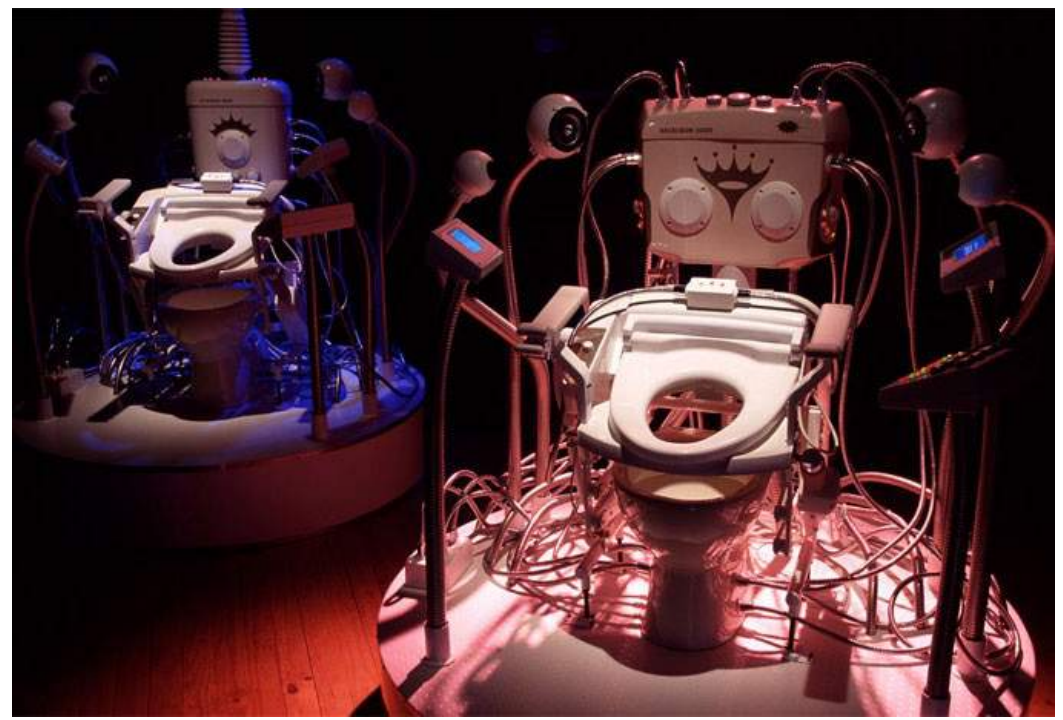

lan Haig, Excelsior 3000, 2001.

subcategory shit in the Collection of Ordure and elevation into art. ${ }^{32}$ The visit in Dresden ended with a telling performance - at least that is what the artist wants us to believe - in which Sirb alias Brisley climbed a pile of wood on a chair with a handful of shit in order to raise its status 'at odds with the compulsion for it to be directed downwards to the ground and further below, consigned to the lower levels, and to be accorded the lowest condition of base production in human affairs.' Brisley's Museum of Shit is now called the UK Museum of Ordure $(U K M O)$. Sirb is its curator, and he even took the initiative to set up the Ordure Organization that advises the UKMO and lends out its objects to exhibit. It is clear that Brisley, who has been interested in garbage and shit for many years, is working out a fascinating fantasy about a worrying reality: a world filled up with waste material. He uses a broad spectrum of means, from works of art to performances and texts; his foremost goal is to let the public realize that next to a pristine side of life there always exists a disgusting one. By elevating ordure to a work of art and exhibiting it in galleries and museums, he forces people to acknowledge that we are the ones who produce it and therefore should not avoid or taboo it, for that would mean a denial of the wholeness of the human experience.

Ordure is an ever-present shadow signifying to all that is deemed unworthy. Unwanted discarded debris induces choking urbanisations, smearing land and urban scapes alike. It thrives in

32 This quote and the next come from Talking Hygiene. Dresden December 2000 by R.Y. Sirb as found on the disappeared site http://dump.ordure.org./www.ordure.org/291/talking-hygiene.html. In a slightly revised form this text can be read in Brisley (2003, 44/45). However, in a new version on the Internet Talking Hygiene, Performance, Dresden the quoted lines do not occur. 
the sway of the brutalising exploitation of natural materials and processes usually dealt with elsewhere, (where labour markets are cheap). The interface is filled with abrasions, natural disasters, and human sacrifices. The world is a rubbish dump. Aesthetics profits from such profligacy. ${ }^{33}$

Whereas Brisley, like Manzoni and so many others, still uses real faeces in his works and performances, the Belgian artist Wim Delvoye produces excrement in an artificial way with the help of an ingeniously constructed machine properly called Cloaca, which he exhibits in galleries and museums. ${ }^{34}$ The first time one could see the machine working in a museum was in Antwerp in the Fall of 2000, where it was fed twice a day as if it were a human being. ${ }^{35}$ The shit produced there was first conserved and then put in glass bottles that one could buy together with a menu of the food fed to Cloaca for $\$ 1,000$ apiece. In the art magazine Flash Art of July-September 2002 (vol. XXXIV, nr 225), Delvoye had a three-page advertisement in which, in a Manzonian way ${ }^{36}$, he sought attention for 'Cloaca Faeces' in a manner not easy to distinguish from advertisements for ordinary consumption goods: 'Each of these Cybershits are unique pieces of art. "Cloaca Shit" is now specially freeze-dried, sterilized, vacuum-packed, dated and signed

${ }_{33}$ This quote comes from a text on another disappeared site, that is, http://www.ordure.org/main.html. Though I have tried to trace this text via Brisley's CV on the Internet, I was not successful. See for an overview of Brisley's work Newman (2015). A similar kind of message as in the quote is succinctly contained in the lines on the cover of Brisley's book (2003): 'Dirt is universal, a-historical even. Homogeneity at ground level, mediated by the universal glue of sputum and excreta. Differentiated at the surface by the droppings of local and global consumption, the deposits of fast food, broken furniture, news media debris, plastic bags, condoms, sanitary towels, cigarette butts, betting slips, syringes etc.' Not only the use of the word 'homogeneity' but the whole content of Brisley's lines recalls the work of Bataille, who stated that the excessive presence of energy on the surface of the globe destines man 'to that glorious operation, to useless consumption' (Bataille 1991, 23).

34 Delvoye became widely known for his work Mosaic, consisting of glazed tiles with images of his own faeces arranged geometrically and shown at the art exhibition Documenta IX in Kassel (Germany) in 1992 (Lange 2002). The artist Heinrich Anton Müller constructed remarkable machines 'en faisant tenir certaines de leur pièces mécaniques au moyen d'excrément' (Ardenne 2001, 242), whereas Cornelius Kolig designed machines for defecation (Hadolt 1999, 180).

35 The idea to construct such a machine already came up in the early nineties. Since 2000 Delvoye continued to build new shit producing machines. Next to the first, Cloaca Original, there exist: Cloaca New \& Improved, Cloaca Turbo, Cloaca Quattro, Cloaca Nr. 5, Personal Cloaca, Mini Cloaca, Super Cloaca, Cloaca Professional and Cloaca Travel Kit. They differ qua amount of shit they produce, their size and the number of meals they get per day (Marcadé 2012, 65, Duquenne 2012, 25).

${ }^{36}$ Bexte has pointed out that Delvoye's Cloaca differs from Manzoni's Merda d'Artista, because the former's machine shows what remains hidden in the latter's tin cans (Bexte 2002, 12). With a gesture in the direction of Benjamin, Bexte also observes: 'In the age of its technological reproducibility, Merda d'artista emancipates itself from the artista. And so Cloaca draws a line under decades of debate' (Bexte 2002, 13). Whereas Delvoye made the digestive process visible by means of a machine, the artist Mona Hatoum used an endoscopic camera in her film Corps Étranger (1996) to show what went on in her intestines (Marks 2000, 189). 
by the artist.' The price had increased, for the product now cost $\$ 1,500 .^{37}$ What also makes the advertisement look like an ordinary ad is that the Cloaca logo seems to be a clever combination of the logo of Coca Cola and that of Ford (Sterckx 2002, 30). ${ }^{38}$ In the meantime Delvoye's shit machine has become the topic of many a study by art historians (Lange 2002), and is widely referred to on the Internet. It clearly evokes many interpretations, ranging from being a device that cleverly puts our stance toward intimacy and privacy into question, to representing a beautifully constructed apparatus that forces us to reflect upon the rapidly increasing ability to create machines capable of duplicating human activities as well as the ongoing cyborgization of the human body. ${ }^{39}$ If one realizes that another of Delvoye's artistic projects involves tattooing pigs as if they were a kind of human beings, then one cannot but conclude that he seems to be very interested in the erosion of the discontinuity between man and machine, on the one hand, and of that between man and animal, on the other. Apart from this, I think that one of the main attractions of Delvoye's sophisticated shit machine consists in the fact that it strongly reminds us of the ways in which, in our highly industrialized society, the fabrication of mass products and their consumption hang together both with the pollution of our globe and the prosperity of at least a large part of the population living on it. It not only seems to concern a mechanical reproduction of 'the most necessary and ordinary act in the world, because [the artist] knows that waste can be turned into gold,' as Martin $(2002,10)$ has suggested, but also - and maybe even more - a piece of art that points to a fascinating cycle in which food and manure, gold and shit, or capital and waste belong together as the two sides of a coin.

Another artist who also builds machines that have to do with faeces is the Australian Ian Haig. He developed the Excelsior 3000, a kind of super-toilet equipped with a computer and other technological gadgets that enable one to download videos and sounds from the Internet while one is using it to empty his bowels. The toilet was shown in 2001 at the Experimenta Media Arts 'Waste' Exhibition in Australia. In an interview with Elisa Berg, Haig explained that his primary interest is not to shock with his work, but to bring an end to our removed and distanced experience of such natural phenomena as shitting, eating and farting. He wants to see toilets as extensions of and mere interfaces with the body or - more precisely - our digestive system and our bowels. Upon her question

\footnotetext{
37 This selling of shit not only reminds one of Manzoni, but also of the Indonesian artist Heri Dono, who ingeniously collected the farts of six farteurs in jars during an installation performance called Semar Kentut (Semar Farts) or PHARTY Semar in Auckland in 1999. The jars with the international sign for radiation on the lid, oval brand-type labels on the front and a list of ingredients of the food eaten by the farteurs on the back were later taken to a local flea market to be sold. Some of them ended up as art objects in Archill Gallery in Grey Lynn, New Zealand (Behrend 1999).

38 The signature of Delvoye seems to be inspired by Walt Disney's. Interesting in the ad is also a smiling man in a white T-shirt whose underbelly consists of nothing but entrails. Delvoye has also shown the inside of a human being elsewhere, for example in X-rays of people having sex that he incorporated in stained glass reminiscent of the stained glass windows in churches; but here holy figures are joined by couples engaged in fellatio and other sexual activities. In a sense he is making another, darker and tabooed side of life transparent with these remarkable pieces of art.

39 Delvoye is also very explicit where it concerns the use of Freudian interpretations of his Cloaca project. According to him it will not be helpful at all for a correct understanding of his work, but one is, of course, free to try to make sense of it from a psychoanalytical perspective. For him, however, it has everything to do with economics. Defecation is what Bataille called the 'damned part' of an economy organized around loss and waste (Marcadé 2012, 56, 61/62, 68).
} 
whether he was interested in the "notion of technological obsolescence in the way computers quickly become a kind of waste product,' he answered:

\begin{abstract}
Absolutely, I think we're not really going to be doing anything interesting with the technology of 2001 until we actually see it in a trash-and-treasure context... (...) ...certainly that idea of obsolescence is an interesting one, the idea that what we're doing with computers is constantly obsolete, it's like there's always something on the drawing board that's going to be released that's going to make anything we're using today completely useless and nothing turns to waste faster than computers (emphasis mine).
\end{abstract}

Upon Berg's salient observation that Excelsior 3000 could be seen as simply a metaphor for the by products of our consumer culture, for why else was it shown at an exhibition called 'Waste,' and that Haig belonged to a (growing) category of artists and writers worrying about the increasing amount of waste produced by this culture and capitalism, the media artist responded by stating that technology actually no longer stood for progress but instead for devolution and regression. ${ }^{40}$

But along with Haig, there have been more artists who presented toilets as art pieces, for example, Cody Choi, who created Cody's Legend, Freud's Shit Box (L'Art 1999, 25), and Mike Kelley, who exhibited his Address System (a toilet for children) and Primaling Cabinet (a transportable lavatory) at Documenta IX in Kassel 1992 (Hoet 1992, 322-23). At the same exhibition, the Russian artist Ilya Kabakov was also present with a toilet (Steevensz 1995:25). It was a small building that from the inside looked like a living room because of all the furniture it contained, for example, a set table with plates suggesting that people were drinking and eating there, too. In his comment upon this installation, Hoet says that The Toilet of Kabakov is 'a Lebensraum' and that everything in it 'points to an outside, to our society' but a society that remains 'in front of the door' (Hoet 1992, 348). The presence of three toilets together with Wim Delvoye's scatological work Mosaic or his turd tiles in Kassel can be called remarkable; faeces and shitting were for the first time emphatically present at an important art exhibition. Hoet apparently had a good nose for the growing popularity of excrement among artists. But I think that I have to disagree here with Documenta's curator; Kabakov's artwork not only refers to our consumer society, it also represents and reflects it in a symbolic or metaphorical way. In this sense one might compare it to Brisley's Museum of Ordure.

In sum, one can discern the following development. There is an age-old tradition in painting, drawing, etching and sculpting of depicting shitting (and pissing) people that has not yet come to an end and probably will never end. In the $19^{\text {th }}$ and $20^{\text {th }}$ centuries, such artists as Ensor, Miró, Dalí, Mühl and Nerdrum worked in this tradition. However, after the Second World War a new trend set in, for then the radical and volatile genre of performance art appeared on the stage in which the body, its (gendered) nature and its

\footnotetext{
40 The source of the information on lan Haig's Excelsior 3000 and Elisa Berg's interview was the site: http:// www.abc.net.au/arts/digital/stories/s443349.htm that does not exist any more. See instead http:// www.ianhaig.net/index.php? section=project\&name=install\&num=21 (accessed May 4, 2017).
} 
functioning played a dominant and crucial role. Shit and toilets became important ingredients along with other bodily fluids, such as blood, sperm and urine, in the happenings, installations and expositions of performance artists. Manzoni and the Wiener Aktionisten played a trailblazing role in this respect. After them, a whole series of artists got involved in what can be called the scatological movement of the late $20^{\text {th }}$ century and the beginning of the 21 st. Some went on in a Manzonian direction (such as Brisley and Delvoye) by elevating faeces produced by themselves, others and even machines as artistic products per se that one could buy and eventually exhibit. Others processed the excrement of animals and humans in their artworks. I will now try to present some interpretations of this remarkable development in the art scene that caused so many scandals and negative reactions, especially in the Western world where it originated.

\section{Making Sense of Shit Art}

Almost all the scholars paying attention to the scatological movement come from other disciplines than sociology and anthropology. Of course, this is a direct outcome of the division of labour within the academic world. However, as an anthropologist interested in the 'wild (in the) West,' in cultural and social phenomena occurring in the occidental world that lead us away from the 'orderly' and 'neat' towards what is considered to be 'chaotic,' 'disgusting,' 'decadent,' and 'abject,' I not only think that I can contribute to a better understanding of the often unsettling work of scatological artists, but also that we can learn from their approach to the world we live in (Verrips 2001b). I want to start with Julius' idea that faecal art can be classified as transgressive art of the taboobreaking type (Julius 2002, 107). The two other transgressive types he distinguishes are an art that breaks art's own rules and a politically resistant art (Julius 2002, 102). Faecal artists intentionally 'put under threat certain under-articulated or unspoken sentiments and beliefs to which audiences may be taken to adhere' (Julius 2002, 111). I think that Julius is perfectly right in stating that artists producing scatological works often have the intention to shock or even de-shock their audiences by showing or using excrement where it is out of place. However, this certainly is not all there is to say about these works. Such an interpretation is limited in that it fails to appreciate that many shit artists also have the purpose to transgress existing stylistic rules in the art scene (this surely holds true for the performance artists) and/or to present a kind of political-aesthetic statement about the (glocal) society they live in. As long as people perceive human faeces as abject matter that one has to get rid of in private and to keep out of the public realm, there will be cases in which exactly the opposite will happen, because as Bataille rightfully observed: taboos are there to be broken. By surrendering themselves to (mimetically) trespassing taboos or just watching the products of this trespassing, people can come into contact with aspects or dimensions of themselves from which these taboos have alienated them. In this sense, taboo breaking (actively as actor or passively as spectator) can be understood as an expedition towards repressed aspects of the self, an expedition that might have a correcting effect on the self-image. Temporary surrender to or 'possession' by the 'wild' enables one to get to know the other (the other who is also oneself) within oneself (Kramer 1987). But interpreting shit art as merely a case of taboo breaking does not tell us much about possible alternative meanings of this particular genre as it developed in the last decades of the $20^{\text {th }}$ century. 


\section{...The big question then is what kind of economic, social and cultural extremes that one should dare to face and/or refrain from could be implied in the scatological genre.}

To trace these meanings, I want to briefly put two anthropologists on the stage: Mary Douglas and Claude Lévi-Strauss. Since the body plays such a prominent role in shit art, I think that it is relevant in this context to refer to the following insight of Douglas: 'The physical experience of the body, always modified by the social categories through which it is known, sustains a particular view of society. There is a continual exchange of meanings between the two kinds of bodily experience so that each reinforces the categories of the other' (Douglas 1982, 65). Douglas, as no one else before, made clear how the parallel between the physical and the social body plays a dominant role in the perception of what is considered pure and impure, good and bad, safe and dangerous, and - as I would like to add - civilized and uncivilized, as well as food/consumptiongood/commodity and shit/waste/garbage. In other words, people, including artists, use the body and its functions to think about and convey messages about collections of bodies, i.e., categories, groups, communities and societies, and vice versa.

Lévi-Straus pointed out that the myths of so-called primitive peoples contain speculations about inherent and latent social and cultural possibilities. Extreme positions are 'imagined in order to show that they are untenable' (Lévi-Straus 1968, 85). I once launched the idea that this insight holds also true for horror films, which often excel in staging an almost unbridled violence towards the human body and in which blood is all over the place. In these films, so I argued, 'the abject,' that abhors and fascinates at the same time, is explicitly shown with the (implicit) purpose of stimulating audiences to refrain from it and stay on what is deemed to be the right economic, social and cultural track (Verrips 2001a). Though one should be careful with a comparison, I think that the family resemblance between myths and horror movies, on the one hand, and shit art (especially scatological performances), on the other, is great enough to also apply LéviStrauss' observation to the kind of art I am dealing with here. The big question then is what kind of economic, social and cultural extremes that one should dare to face and/or refrain from could be implied in the scatological genre. I think that there are - along with the one already mentioned, i.e., the breaking of a taboo - at least two that should be kept in mind when trying to make sense of shit art. The first extreme seems to lie in the realm of civilization and the second in that of production and consumption. Let me concentrate now on the first extreme that in my view shit art touches upon, the one related to civilization.

As I have shown, there are a number of artists who use faeces in their work, especially in performances. Along with shitting (and urinating) in public places, they sometimes smear faeces (or substitutes such as chocolate) on their own bodies and/or on those of others participating in their happenings. Some of the Wiener Aktionists garnered fame as well as contempt with doing this. Several authors (see, for example, Vogel 1997, 250) have pointed out that the message conveyed by these scatological performances- as Frazer observed a long time ago - is that people should not forget 'the permanent existence of...a solid layer of savagery beneath the surface of society' and our moving 
'on a thin crust which may at any moment be rent by subterranean forces slumbering below' (Frazer 1922, 236). What is at issue in the scatological performance art since the second half of the $20^{\text {th }}$ century up till now is what Frazer not only deemed possible but also feared, namely that Westerners could get trapped in an alarming de-civilization process, as they were, for instance, during the Second World War and similar large-scale disasters. Smearing shit, this smelly bodily waste that each and every one of us carries inside and has learned to hide and even fear, on the skin symbolically shows the everpresent human ability to indulge in all kinds of humiliation of and uninhibited aggression, violence and cruelty toward fellow human beings (as well as other living creatures), in short to waste lives. The artists tell their audiences so to speak in a metaphorical way not to forget that we all have a dark, uncivilized side, that we all carry 'shit' in us and always are able to lose our civilized masks, to break rules and laws and in doing so to create havoc in a more or less serious manner. By painting (with) shit(ting bodies) and/or smearing what is inside their bodies on their outside, artists express a specific view of the very fragile nature of our capacity to always remain the civilized creatures we think we are. They hold up a mirror and invite their audiences to look into it and to eventually remember what they saw in it: 'shit' that one should try to stay away from. This turning things upside down, or better: inside out, reminds one of what also happens during carnival and rituals of rebellion, as described and analysed by the anthropologist Max Gluckman (1954), which in the last instance serve, both humorously and seriously, the continuity of what is valued: an orderly and civilized society in which no body is seen as waste and is therefore wasted.

\section{...By painting (with) shit(ting bodies) and/or smearing what is inside their bodies on their outside, artists express a specific view of the very fragile nature of our capacity to always remain the civilized creatures we think we are.}

Now I want to come back to the family resemblance I touched upon earlier between the artistic scatological performances and what happened in prisons in Northern Ireland in the late 1970s, on the one hand, and the Abu Ghraib prison in Iraq in the beginning of the 20 first century, on the other. During the Dirty Protest the prisoners did the same thing as the artists, they soiled themselves with faeces, whereas in Iraq the prisoners were ordered by their guards to do this. In these two cases the issue of being civilized or not also played a role. The Irish prisoners conveyed this double message: look, we are now what you think we are: no more than pure shit, but if you think about it carefully, it is you guards and all the ones you represent that are in fact uncivilized barbarians because of the shitty way you treat us (Aretxaga 1995). In Iraq, the guards wanted the prisoners to look exactly like what they stood for in the guards' eyes: 'stinking matter one has to get rid of,' 'pieces of uncivilized shit.' Against the background that the use of faeces as a means to express in words and deeds what one thinks about others whom one deems less civilized than oneself or not civilized at all is age old and widespread; the incorporation of excrement in artistic works took place rather late in time. And this had everything to do with 'the introduction of the body into the art system' after World War II (Weibel 2002, 669). That audiences were so often shocked by the appearance of shit in such an unexpected context as the art scene tells us more about their blindness for its frequent use as a metaphor for being corrupt and/or uncivilized in other contexts and discourses 
than it does about the assumed decadent habitus or lack of decency of the artists who brought it as a work of art into galleries and museums. How powerful shit as a metaphor can be, comes to the fore when these artists are compared to nothing less than this bodily waste. ${ }^{41}$

Let me now turn to the other extreme that is touched upon in scatological artistic work that either consists of just shit, waste, and/or garbage, as in the case of Arman, Brisley and Kabakov, or of faeces in the shape of a commodity or industrially produced consumption good, as in the case of Delvoye and Manzoni. In the foregoing I already noted that, via their works, several scatological artists convey particular messages about consumer capitalism as it developed and blossomed in the second half of the $20^{\text {th }}$ century and thereafter, and that one can see their art as a revealing comment on our neo-capitalist society and culture. If one takes into consideration what they themselves every now and then say about their works in interviews and texts, one can only conclude that they have great worries about the ways human beings are busy transforming the globe at high speed into one big rubbish dump as a consequence of our overheated system of production, distribution and consumption and that they wanted to express these concerns. Their work shows symbolically and metaphorically the extreme of neocapitalistic greed and gluttony in all its negative facets. This also happens in other genres with a strong scatological character, for example in popular entertainments like the South Park cartoon show (Gardiner 2000, Larsen, 2001). These artists deal with the seemingly eternal cycle of transforming raw materials, as if they were inexhaustible, into ever more shining and highly desirable mass goods first and, later, after they have been consumed, into shit, rubbish and waste that spoils the environment. They use faeces, the shitting body and by extension the toilet as metaphors for the reality of the enormous waste production in the world, especially the Western world. That is the extreme their work deals with in the hope that it will touch and shock us. Once again, the correctness of Mary Douglas' insight that people think with the natural body about the social body and vice versa is splendidly confirmed. An installation like Cloaca by Wim Delvoye confronts us with the anus of the consumer society or the anus mundi and the shit that comes out of it. The work of the German philosopher Peter Sloterdijk might provide (part of) the answer to the question why artists like him began to draw attention to this dark side of our existence on the globe in the last decades of the $20^{\text {th }}$ century. In his famous Kritik der zynischen Vernunft (1983), Sloterdijk states that the way we have learned to relate to our own faeces, that is, as something to negate, has functioned until recently as the model for our relation to garbage and waste. Only after the rise of modern ecological thinking has garbage returned to our consciousness and with it the critique of man as 'a hyperproductive, shit-accumulating, industrial animal.' Those who do not want to admit that they produce waste and that, as a matter of fact, they have no choice to become

\footnotetext{
41 See Hadolt (1999) for a fascinating description and analysis of the late-1990s debate in Austria about the commission given to the Austrian artist Cornelius Kolig, who uses shit in his works and designed machines for defecation, to restore a fresco painted by his grandfather Anton Kolig in a hall of the Carinthian Provincial Parliament and that was destroyed by the Nazis in 1938 as 'Entartete Kunst.' During the Kulturkrieg, as Hadolt calls the debate, Kolig was scorned by his opponents, who considered themselves civilized and 'clean,' for being one of these Austrian Fäkalkünstler (shit artists) who soiled his own nest. They even accused him of being a piece of shit himself. Thus, when attacking the artist for using shit in his work, his opponents frequently used 'ribald faecal speech.' In connection with this, see Kleeblatt (1993), who studied excremental caricature attacks on Emile Zola for producing excremental literature
} 
something else, says Sloterdijk, take the risk of choking in their own shit. Thanks to the growing ecological consciousness, waste has become a 'higher' issue, a topic on the agenda. The brilliant philosopher then continues with a penetrating call to radically change our approach to shit and waste. We should start again to seriously think about the usability of the unusable, the productivity of the unproductive or - in more abstract terms - the positive sides of the negative. A cynical man is not disgusted by anything, but is just like a child that does not know yet how negative shit is deemed to be. ${ }^{42}$ It seems that at least Delvoye, who every now and then has referred to passages in Sloterdijk's work on the pariah status of the anus, implemented the writer's call by creating Cloaca. Other artists did not read the German philosopher, but made pieces of art in the same vein as the Belgian artist. Fascinating is how their work plays with the classic association of money with shit (Borneman 1973) and how they, for example Manzoni, symbolically elevate faeces to the same level as capital and vice versa as also happens in fairy tales and folklore. ${ }^{43}$ Originally, the equation was more positive because it was grounded in the fact that excrement was used as manure, but with the advent of industrial capitalism it became more negative because the significance of faeces as fertilizer rapidly decreased and the problem of garbage and waste production correspondingly increased. I will resist the temptation to say more about this topic. Instead I wish to conclude with the following. If one is inclined to interpret shit art as nothing more than a decadent effort to shock audiences by breaking the taboo on bringing shit out of the toilet into public places like museums, then one overlooks at least two things: that this art directly relates to and comments upon a) the fact that, time and again (for example, during the Second World War), the degree of human civilization in the Western world turned out to be not as high as pretended and b) the fact that humans are busily transforming the globe into a waste dump, where consumption counts more than conservation and money more than all the shit and waste this consumption generates. In a certain way, this art thus represents a particular, but nevertheless very sensitizing (re)presentation and critical diagnosis of important phenomena in the Western world. Precisely for this reason, one could argue that, at least in several respects, the artists I have dealt with in this essay look much like anthropologists critically investigating their own culture and society. ${ }^{4}$

\footnotetext{
42 For a similar perspective, see Bataille's essays The Use Value of D.A.F de Sade and The Psychological Structure of Fascism, written before World War II, in which he deals with the sacred character of things that are rejected by the homogeneous society (in which the elementary form of appropriation is oral consumption) as disgusting 'waste,' for example, the waste products of the human body, and about how precisely these things are highly valued in a heterogeneous world (in which excretion excels) (Bataille 1994, 91-105, 137-161). In this connection the fascinating ideas of Marcel Duchamp about a great transformer that could utilize wasted energies, such as the fall of urine and excrement, are to the point (see Girst 2014,178).
}

43 One such famous fairy tale is the one about the money-shitting donkey. In this connection, the very popular German term Dukatenscheisser, a man that shits money, is also interesting (Dundes 1987, 73, 95), not the least because he shows a fascinating family resemblance to people who nowadays want to become rich by transporting drugs in their bowels. Salient fact: the dealers in Amsterdam who sell the drugs later carry them in their mouths and spit in the hands of the addicts after the stuff is paid for!

44 Linda Kauffman came to a similar conclusion when she wrote with reference to Kiki Smith's Tale: 'I said earlier that many of the artists, filmmakers, and novelists in my study are like anthropologists, investigating an alien culture' (Kauffman1998, 44). 
Adamowicz, Elza. 2003. Exquisite excrement: the Bataille-Breton polemic. Aurifex 2.

Alfano Miglietti, F. 2003. Extreme Bodies. The Use and Abuse of the Body in Art. Milano: Skira.

Ardenne, Paul. 2001. L'Image corps. Figures de l'humain dans l'art du XXe siècle. Paris: Éditions du regard.

Aretxaga, Begoña. 1995. 'Dirty Protest: Symbolic Overdetermination and Gender in Northern Ireland Ethnic Violence.' Ethos 23(2):123-48.

Bataille, Georges. 1991. The Accursed Share. Vol. I. Consumption. Translated by Robert Hurley. New York: Zone Books.

Bataille, Georges. 1994. Visions of Excess. Selected Writings, 1927-1939. Edited and with an Introduction by Allan Stoekl. Translated by Allan Stoekl et al. Theory and History of Literature, Vol. 14. Sixth Printing. Minneapolis: University of Minnesota Press.

Behrend, Tim. 1999. 'The Millennial Esc(h)atology of Heri Dono: "Semar Farts" First in Auckland, New Zealand.' Indonesia and the Malay World 27(79):208-24.

Bexte, Peter. 2002. 'Angels with Shitty Wings.' In Wim Delvoye Scatologue. edited by Regina Lange, 11-21. Gent: MERZ/Luc Derycke \& Co.

Borneman, Ernest. 1973. Psychoanalyse des Geldes. Eine kritische Untersuchung psychoanalytischer Geldtheorien. Frankfurt am Main: Suhrkamp Verlag.

Brisley, Stuart. 2003. Beyond Reason: Ordure. London: Book Works.

Canning, Susan M. 1993. 'The Ordure of Anarchy. Scatological Signs of Self and Society in the Art of James Ensor.' Art Journal 52(3):47-53.

Collective. 1999. L'Art au corps. Le corps exposé de Man Ray à nos jours. Marseille: Musées de Marseille-Réunion des musées nationaux.

Dixon, Laurinda S. 1993. 'Some Penetrating Insights. The Imagery of Enemas in Art.' Art Journal 52(3):28-35.

Douglas, Mary. 1966. Purity and Danger. An analysis of Concepts of Pollution and Taboo. London: Routledge and Kegan Paul.

Douglas, Mary. 1968. Natural Symbols. Explorations in Cosmology. With a new introduction by the author. New York: Pantheon Books.

Dubin, Steven C. 1999. Arresting Images. Impolitic Art and Uncivil Actions. London and New York: Routledge.

Dundes, Alan. 1987. Sie mich auch! Hinter-Gründige in der deutschen Psyche. Aus dem Amerikanischen von Aurel Ende. München: Deutscher Taschenbuch Verlag.

Duquenne, Olivier. 2012. 'In de huid van Wim Delvoye.' In Wim Delvoye Introspective, 15-31. Brussel: Mercatorfonds.

Esty, Joshua D. 1999. "Excremental Postcolonialism." Contemporary Literature 40(1): 22-59.

F.G. 2002. 'Review of Transgressions: The Offences of Art, by Anthony Julius.' Modern Painters 15(4):164-65.

Frazer, James George. 1922. The Golden Bough. A Study in Magic and Religion. Part I The Magic Art and the Evolution of Kings. Vol. 1. Third Edition. London: Macmillan and Co.

Funken, Peter. 1998. Blalla W. Hallmann. Eine Retrospektive. Kunstforum 140:350-51.

Fusco, Coco. 2001. The Bodies That Were Not Our Own: And Other Writings. London and New York: Routledge. 
Gardiner, Judith Kegan. 2000. 'South Park, Blue Men, Anality, and Market Masculinity.' Men and Masculinities 2(3):251-72.

Girst, Thomas. 2014. The Duchamp Dictionary. London: Thames \& Hudson.

Gluckman, Max. 1954. Rituals of Rebellion in South-East Africa. Manchester: Manchester University Press.

Hadolt, Bernhard. 1999. 'Shit and politics: The case of the Kolig-debate in Austria.' Medische Antropologie 1 1(1):179-99.

Hennig, Jean-Luc. 1998. Der Hintern. Geschichte eines markanten Körperteil. Aus dem Französchen von Sabine Lorenz und Felix Seewöster. München: Piper Verlag.

Hoet, Jan. 1992. 'documenta als Motor' Ein Rundgang durch die DOCUMENTA IX.' Kunstforum 119:220-503.

Jones, Amalia. (1998) Body Art/Performing the Subject. Minneapolis: University of Minnesota Press.

Julius, Anthony. 2002. Transgressions. The Offenses of Art. London: Thames \& Hudson.

Kauffman, Linda S. 1998. Bad Girls and Sick Boys. Fantasies in contemporary art and culture. Berkeley: University of California Press.

Kleeblatt, Norman L. 1993. 'MERDE! The Caricatural Attack against Emile Zola.' Art fournal 52(3):54-59.

Kramer, Fritz. 1987. Der rote Fez. Über Besessenheit und Kunst in Afrika. Frankfurt am Main: Athenäum.

Kristeva, Julia. 1988. Powers of Horror. An Essay on Abjection. Translated by Leon S. Roudiez. New York: Columbia University Press.

Lange, Regina, ed. 2002. Wim Delvoye Scatologue. Gent: MERZ/Luc Derycke \& Co.

Laporte, Dominique. 2000. History of Shit. Translated by Nadia Bernabid and Rudolpe el-Khoury. Cambridge, Mass.: The MIT Press.

Larsen, David. 2001. 'South Park's Solar Anus, or, Rabelais Returns. Cultures of Consumption and the Contemporary Aesthetic of Obscenity.' Theory, Culture $\mathcal{E}^{\circ}$ Society 18(4):65-82.

Lévi-Strauss, Glaude. 1967. 'The Story of Asdiwal.' In The Structural Study of Myth and Totemism., edited by Edmund Leach, 1-49. London: Tavistock.

Marks, Laura U. 2000. The Skin of the Film. Intercultural Cinema, Embodiment, and the Senses. Durham and London: Duke University Press.

Marcadé, Bernard. 2012. 'Het argot van Wim Delvoye.' In Wim Delvoye Introspective, 31-80. Brussel: Mercatorfonds.

Martin, Jean-Hubert. 2002. 'From the Body Lab.' In Wim Delvoye Scatologue, edited by Regina Lange, 7-11. Gent: MERZ/Luc Derycke \& Co.

Menon, Elisabeth K. 1993. 'Potty-Talk in Parisian Plays. Henry Somm's La Berline de l'émigré and Alfred Jarry's Ubu roi.' Art Fournal 52(3):59-64.

Monk, Philip, et al. 2000. Mike Kelley and Paul McCarthy : Collaborative Works. Toronto: The Power Plant Contemporary Art Gallery.

Newman, Michael. 2015. Stuart Brisley - Performing the Political Body and Eating Shit. Belfast: the MAC.

Noever, Peter, ed. 1998. Otto Mühl 7. Ostfildern: Cantz Verlag.

Persels, Jeff and Russell J. Ganim, ed. 2004. Fecal Matters in Early Modern Literature and Art. Studies in Scatology. Studies in European Cultural Transition, Volume Twenty One. Aldershot Hampshire: Ashgate Publishing Limited. 
Roundtable. 1994. 'The Politics of the Signifier II: A Conversation on the Informe and the Abject.' October 67:3-23.

Schneider, Rebecca. 1997. The Explicit Body in Performance. London and New York: Routledge.

Silk, Gerald. 1993. 'Myths and Meanings in Manzoni's Merda d'artista.' Art fournal 52(3):65-75.

Sloterdijk, Peter. 1983. Kritik der zynischen Vernunft. Frankfurt am Main: Suhrkamp Verlag.

Stallabrass, Julian. 1999. High Art Lite. British Art in the 1990s. London: Verso.

Steevensz, Bert. 1995 'De gespleten wereld van Ilya Kabakov.' Metropolis M 5:24-30.

Sterckx, Pierre. 2002. 'Wim Delvoye.' In Wim Delvoye Scatologue, edited by Regina Lange, 21-34. Gent: MERZ/Luc Derycke \& Co.

Verrips, Jojada. 2001a. 'The State and the Empire of Evil.' In Powers of Good and Evil. Social Transformation and Popular Belief, edited by Paul Clough and Jon P. Mitchell, 185-210. New York \& Oxford: Berghahn Books.

Verrips, Jojada. 2001b: 'The Golden Bough and Apocalypse Now: an-other fantasy.' Postcolonial Studies 4(3):335-51.

Voge1, Amos. 1997. Film als subversive Kunst. Aus dem Englischen übersetzt von Felix Bucher et al. St. Andrä-Wördern: Hannibal Verlag.

Weibel, Peter. 1970 Wiener Bildkompendium Wiener Aktionismus und Film. Frankfurt/M.: Kohlkunstverlag.

Weibel, Peter. 2002. 'An End to the 'End of Art'? On the Iconocasm of Modern Art.' In Iconoclash. Beyond the Image Wars in Science, Religion, and Art, edited by Bruno Latour and Peter Weibel, 570-671. Karlsruhe: ZKM/Center for Art and Media.

Jojada Verrips (*1942) is a Dutch cultural anthropologist, who was from 1997-2007 professor at the University of Amsterdam. He has conducted research on a variety of diverse topics, from Dutch boatmen to fishermen in Ghana, and has also been a careful anthropological commentator and critical thinker of the mysteries of the Western popular culture, and in particular of its more sinister aspects. Corresponding Author: j.verrips@uva.nl 